\title{
Biomechanické a kineziologické aspekty techniky bikrosového startu
}

\section{Biomechanical and kinesiology aspects of the bicross start technique}

\author{
Miriam Kalichová, Sylva Hřebíčková, Martina Bernaciková, Romana Labounková
}

Fakulta sportovních studií Masarykovy univerzity, Brno

\begin{abstract}
Abstrakt
Př́spěvek se zabývá technikou bikrosového startu. Na základě analýzy limitujících faktorů výkonu poukazuje na start jako na jednu z nejdůležitějších fází celého bikrosového závodu. Optimální start je založen na respektování kineziologických a biomechanických zákonitostí, jimiž se v př́spěvku zabýváme. Cílem studie je vytvořit teoretický základ, na nèmž prijde stavět empirické práce zabývající se optimalizací bikrosového startu.
\end{abstract}

\begin{abstract}
The paper deals with techniques bicross start. Based on the analysis of factors limiting the performance start point out, as one of the most important stages in the race. Optimum take off is based on respect for kinesiology and biomechanical patterns, which is this paper dealing with. The aim of this study is to establish a theoretical foundation on which will be built upon empirical work dealing with optimization bicross start.
\end{abstract}

Klíčová slova: $\quad$ bikros, start, kineziologie, biomechanika

Keywords: $\quad$ bicross, start, kinesiology, biomechanics

\section{ÚVOD}

Bikros je považován za atraktivní sport, u něhož má divák dokonalý přehled o dění v závodě. I přesto, že bikros vznikl již v 60. letech minulého století a od roku 2008 je zařazen do programu letních olympijských her, metodikou sportovního tréninku podloženou vědeckými výzkumy tohoto sportu se zabývá málo prací. Nedostatečná publikační činnost $\mathrm{v}$ oblasti bikrosu nás proto vedla $\mathrm{k}$ této teoretické studii zaměřené na bikrosový start, která se vedle dostupné literatury opírá i o zkušenosti ze závodní praxe na mezinárodní úrovni.

\section{CÍL}

Cílem této teoretické studie je předložit přehled současných poznatků o problematice bikrosového startu $\mathrm{z}$ hlediska techniky, biomechaniky a kineziologie této specifické časoprostorové pohybové struktury.

\section{Limitující faktory výkonu v bikrosu}

Bikros patří mezi individuální sporty, kde mezi sebou soupeří až osm jezdců současně. Závody se konají na tratích 300-400 m dlouhých, jejichž profil je typický nerovnostmi a zatáčkami. Cílem každého závodníka BMX je projet danou trat’ v co nejkratším čase. Start závodu se odehrává na nakloněné rovině. Ve startovní poloze jsou všichni na stejné úrovni, což je dáno startovacím zařízením. Mříž, za kterou se jezdci nacházejí, padá se startovním signálem. Následuje průjezd trati, kterou závodníci zdolávají v rozmezí 30 a 40 s (Bertucci a kol., 2007). Rychlosti, kterých jezdci dosahují, bývají přes $70 \mathrm{~km} \cdot \mathrm{h}^{-1}$, a to již několik sekund po startu (Debraux, 2010).

Bikros jako pohyb je arteficiální lokomoce zprostředkovaná pomocí kola. Stř́idají se zde pohyby cyklické a acyklické. K cyklickým patři šlapání, mezi acyklické řadíme technické prvky, jako je skok nebo startovní pohyb. Mateo a kol. (2011) ve své publikaci analyzoval cyklické a acyklické fáze v průběhu závodu a zjištoval, jak technická náročnost acyklických fází ovlivní produkci výkonu a síly cyklických fází. Výsledky ukázaly, že 86,3 \% závodu spočívá v acyklických pohybových činnostech a 16,7\% v činnostech cyklických s tím, že tento poměr se mění v závislosti na profilu a obtížnosti tratě. 
Konečný výkon sportovce ovlivňuje několik faktorů: faktory somatické, kondiční, psychické, faktory techniky a taktiky. Kromě těchto vnitřních faktorů výkon ovlivňuje i vnější prostředí obklopující závodníka (Dovalil, 2002).

Ze somatických faktorů je nejdůležitější podíl svalových vláken, který je dán geneticky. Vzhledem $\mathrm{k}$ charakteru pohybové činnosti je pro bikros důležité zastoupení rychlých svalových vláken. Výška závodníka není u bikrosu rozhodujícím faktorem. Ve světové špičce nalezneme závodníky různého vzrůstu. Jako prŕklad bychom uvedli dva medailisty z Olympijských her v Pekingu, Američany Donnyho Robinsona a Mika Daye, prvního $168 \mathrm{~cm}$ a druhého $197 \mathrm{~cm}$ vysokého. Typickým somatotypem je mezomorf s výraznou hypertrofií svalů stehen a širokými rameny.

Dovalil a kol. (2002) za kondiční faktory sportovního výkonu považuje pohybové schopnosti. Vzhledem $\mathrm{k}$ značné variabilitě pohybových činností při tomto sportu existuje více pohybových schopností limitujících výkon jezdce. Můžeme říct, že závodní jízda je přerušovaný sprint trvající 30-40 s, závodník však jede 4-6 jízd za den a celý závod trvá okolo čtyř hodin. Proto kromě výbušné síly, reakční a akční rychlosti, které jsou nepostradatelné pro rychlý start a akceleraci, je zapotřebí i rychlostní vytrvalost a obecná vytrvalost, aby byl závodník schopen absolvovat každou z jízd v plném nasazení. Předpokladem pro výkon na vysoké úrovni je zvládnutí techniky, což je podmíněno vysokou úrovní koordinačních schopností. Jezdec musí dokonale ovládat své kolo, techniku skoku, jízdu po zadním kole a další dovednosti, které navíc musí umět aplikovat na parametry se lišících dráhách.

Mnoho trenérů a odborníků se shoduje v názoru, že start je jednou z rozhodujících fází závodu, protože cyklista, který se již na začátku dostane před ostatní a v první zatáčce je ve vedení, má oproti soupeřủm jistou výhodu i při překonávání všech dalších překážek a nerovností (Zabala a kol., 2009; Debraux, 2010). Proto je velmi důležitá i technika startu.

Z taktického hlediska není bikros složitým sportem. Závodí osm jezdců současně a situace se neustále mění, jezdec tedy musí umět rychle reagovat na aktuální stav. Je sice možné si před závodem promyslet několik variant, jak by jízda mohla proběhnout, ale v samotném závodě je důležitá schopnost rychle se rozhodovat. Taktizování je možné jen při výběru dráhy na startu. Jezdec si kromě pozice do první zatáčky volí i soupeře, kteří vedle něho na startu budou stát, což pro někoho může, a pro jiného nemusí být psychickou výhodou.

Psychika je velmi podstatným faktorem sportovcova výkonu. Je zapotřebí být stabilním a vyrovnaným jezdcem, který se nebojí jít do osobních soubojů a má dostatečnou odolnost vůči tlaku, který je na něho vyvíjen. Musí být dostatečně motivován a mít velkou vůli absolvovat náročné tréninky.

Vliv na výkon může mít i řada dalších vnějších faktorů, např́íklad znalost dráhy, podpora ze strany fanoušků, zázemí, počasí, soupeři, technický stav kola a podobně.

\section{Průběh bikrosového startu}

Start je jedním z nejdůležitějších determinantů celého závodu, zároveň však jednou z nejkomplexnějších a nejsložitějších fází závodu kvůli vysokým požadavkům jak na koordinaci, tak i na zrychlení. Start je tak podmíněn kombinací úrovně reakční rychlosti, rychlostně-silových a koordinačních schopností (Lefebvre, 2010, Dorémus, 2011). Vedle těchto schopností považuje Gianikellis a kol. (2011) za podstatnou proměnnou ovlivňující kvalitu startu technickou vyspělost závodníka.

Start ze dvou pedálů je v současné době nejrychlejším provedením startu. Startuje se na světelné nebo na zvukové signály. Volba je na každém jezdci. Jezdec stojí za mříží, která svírá se startovní nakloněnou rovinou úhel $90^{\circ}$ a je vysoká $40 \mathrm{~cm}$. Po vysílání elektronicky nahraných slovních povelů se postupně rozsvítí čtyři světla na semaforu, zároveň s každým světlem zazní i zvukový signál. Časová prodleva mezi mluvenými povely a prvním světelným signálem je proměnlivá v rozmezí mezi $0,1-3$ s. Pro rychlý start je proto potřebná skvělá koncentrace a rychlá reakce. Mřiž padá současně s rozsvícením posledního světelného signálu. Mechanismus pádu mřiže je založen na hydraulickém pístu, který ji sráží k zemi. Startovní pohyb je nutné zahájit mnohem dříve, než mříz spadne, aby v době dopadu mříže na zem byl jezdec už $\mathrm{v}$ pohybu směrem vpřed. Zahájení pohybu je u každého individuální, ale u většiny jezdců začíná ihned po zaregistrování prvního světelného nebo zvukového signálu. 


\section{TECHNIKA BIKROSOVÉHO STARTU}

\section{Vývoj techniky bikrosového startu}

Dříve než se závodníci naučili startovat ze dvou pedálů, používali techniku startu jen z jednoho pedálu. Tuto techniku dodnes používají začátečníci. Při tomto způsobu startu je jedna noha na pedálu a jedna na zemi. Nataženýma rukama závodník tlačí kolo proti startovní mříži s trupem co nejvíce vzadu. Pedál má trochu výše, než je vodorovná poloha. Krátce před vlastním startem se závodník odrazovou nohou odráží od země a rychlým posunutím trupu dopředu přenáší švihem značnou pohybovou energii, která umožňuje snadnější sešlápnutí pedálu, a tím i rychlejší start. K tomuto způsobu startu je nutno se naučit i okamžité našlápnutí odrazové nohy, aby závodník mohl zaujmout základní polohu a plnou silou pokračovat v jízdě (Bartůněk, 1990).

Při startu ze dvou pedálů rozeznáváme tři typy startu (Dorémus, 2011):

- tlačený start - používají ho spíše začátečníci;

- $\quad$ klasický start s pohybem kola vzad - nejběžnější způsob startu;

- $\quad$ start „slingshot“ - nejnovější způsob startu zř́ídka používaný;

\section{Přípravná startovní pozice}

Je důležité specifikovat již přípravnou fázi, protože vytváří podmínky pro první pohyby po startovním signálu. Jezdec opře kolo o startovní zařízení. Na svém kole stojí, pedály si srovná tak, aby silnější (záběrová) dolní končetina byla vpředu. Správnou polohu jednotlivých segmentů ukazuje obr. 1. Výška umístění pedálu závisí na sklonu startovního pahorku. „Aby bylo první sešlápnutí pedálu co nejdelší, je třeba, aby se zadní pedál nacházel mezi horizontálou a rovnoběžkou se startovní nakloněnou rovinou. Pata přední nohy bývá mírně protlačena dolů nebo v horizontále, čímž umožňuje lepší udržování rovnováhy. Aby jezdec mohl působit na pedál maximální silou, chodidlo by mělo být umístěno $1 / 3$ před a $2 / 3$ za osou pedálu“ (Dorémus, 2011). Obě dolní končetiny jsou v kolenních kloubech v mírné flexi, Lefebvre (2010) doporučuje úhel 15-45․ Ve statické poloze jde o izometrickou svalovou činnost. Pánev je v mírné retroverzi a nachází se kousek za sedlem. Trup je rovný a zpevněný, což umožňuje optimální přenos sil. „Ramena jsou vysunutá vpřed, loketní klouby jsou v mírné flexi nebo úplné extenzi, zápěstní klouby mírně flektované“ (Lefebvre, 2010, Dorémus, 2011). Poloha paží a zápěstí se může lišit v závislosti na typu startu. Poloha hlavy závisí na druhu podnětu, na který jezdec startuje. Pokud startuje na světelné signály, hlava je zvednutá a jezdec pohledem sleduje semafor umístěný pod startovním pahorkem. Při startu na zvukový signál se jezdec dívá do země těsně za startovní rampou, hlava je tedy v prodloužení páteře. Izometrickou svalovou činností udržuje jezdec tělo v rovnovážné poloze, než zahájí start.

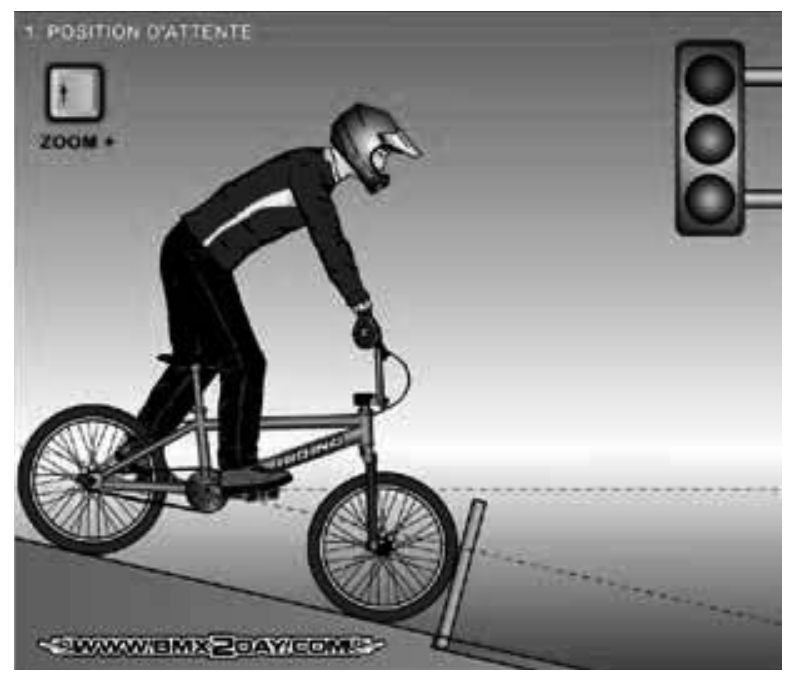

Obr. 1 Přípravná startovní pozice (Převzato od Dorémus, 2011) 


\section{Tlačený start}

Tento start se jezdci učí jako první, obě kola jsou při padání mřiže na podložce. Po startovním signálu následují tyto pohyby těla (Dorémus, 2011): extenze dolní končetiny se současným tlakem na pedál, která je spojena s posunem pánve vpřed, což umožňuje optimální přenos energie. Přitom je nutné zabránit zvednutí pánve, měla by se pohybovat vpřed po trajektorii rovnoběžné s profilem nakloněné roviny. Přesnému pohybu pánve napomáhá zápěstí zapřené o řídítka a pohyb ramen vpřed. Cílem tohoto typu startu je co nejvíce kopírovat pohyb padající mř́iže, $z$ toho důvodu se okamžik před jejím pádem pánev přesouvá vpřed (obr. 2).
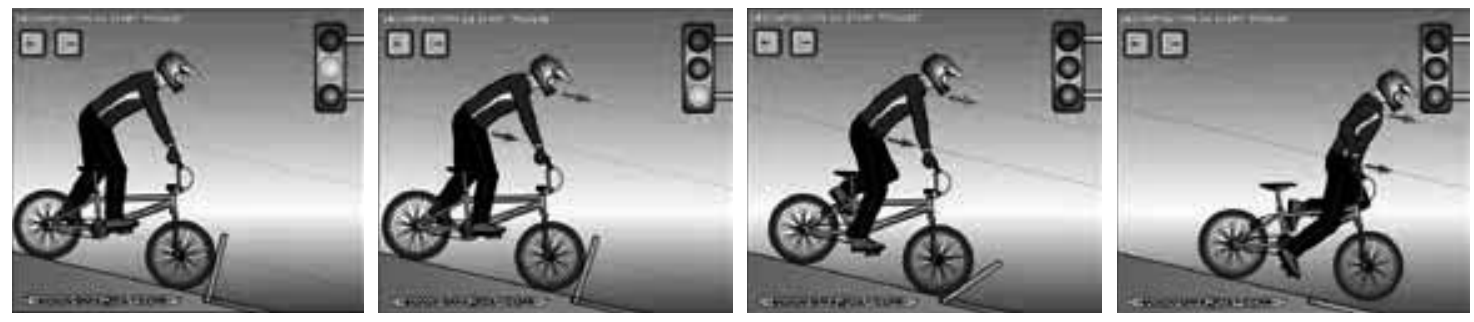

Obr. 2 Kinogram tlačeného startu (Převzato od Dorémus, 2011)

\section{Klasický start s pohybem kola vzad}

Tento typ startu je založen na koordinaci a synchronizaci pohybu těla s pohybem mřiže na základě světelného či zvukového signálu. Lefebvre (2010) i Dorémus (2011) dělí tento start na dvě fáze - fázi pohybu kola vzad a fázi zrychlení neboli fázi výjezdu ze startovního zařízení (obr. 3).

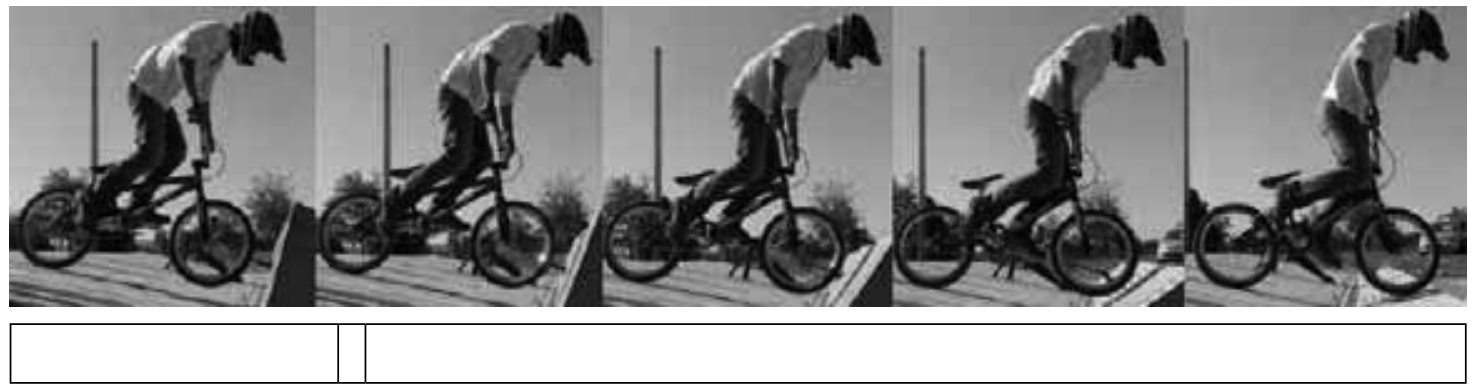

Fáze pohybu kola vzad

Fáze zrychlení

Obr. 3 Fáze klasického startu s pohybem kola vzad (Převzato od Lefebvre, 2010)

\section{Fáze pohybu kola vzad}

Jezdec začíná start mírným pohybem (obr. 4b), přitahuje boky k řídítkům. Současně jdou ramena vpřed, měla by se nacházet přibližně nad řídítky. Krk je v prodloužení páteře, hlava v mírném předklonu tak, aby se jezdec mohl dívat na přední kolo. Paže provádějí mírný tah, čímž jezdec lehce nadzvedne přední kolo, které se pohybuje po elipsovité trajektorii směrem vzad (cca $5 \mathrm{~cm})$. Na konci této fáze by se měly kliky dostat do roviny rovnoběžné s podložkou, nebở v této poloze je nejsnazší vyvinout svalovým působením maximální otáčivý účinek v následující fázi zrychlení.

Dorémus (2011) objasňuje pohyb ramen nad řídítka za prvé tím, že se prodlouží fáze tlaku na pedál, za druhé omezí zvednutí pánve, která by se i při zvednutém předním kole měla pohybovat vpřed po přímce paralelní s nakloněnou rovinou. Pohyby v této fázi se většina kloubních spojení dostává do mírné flexe. Účelem těchto pohybů je kumulovat co nejvíce potenciální energie pružnosti v protažených svalech, aby mohla být následně využita ke konání mechanické práce. 

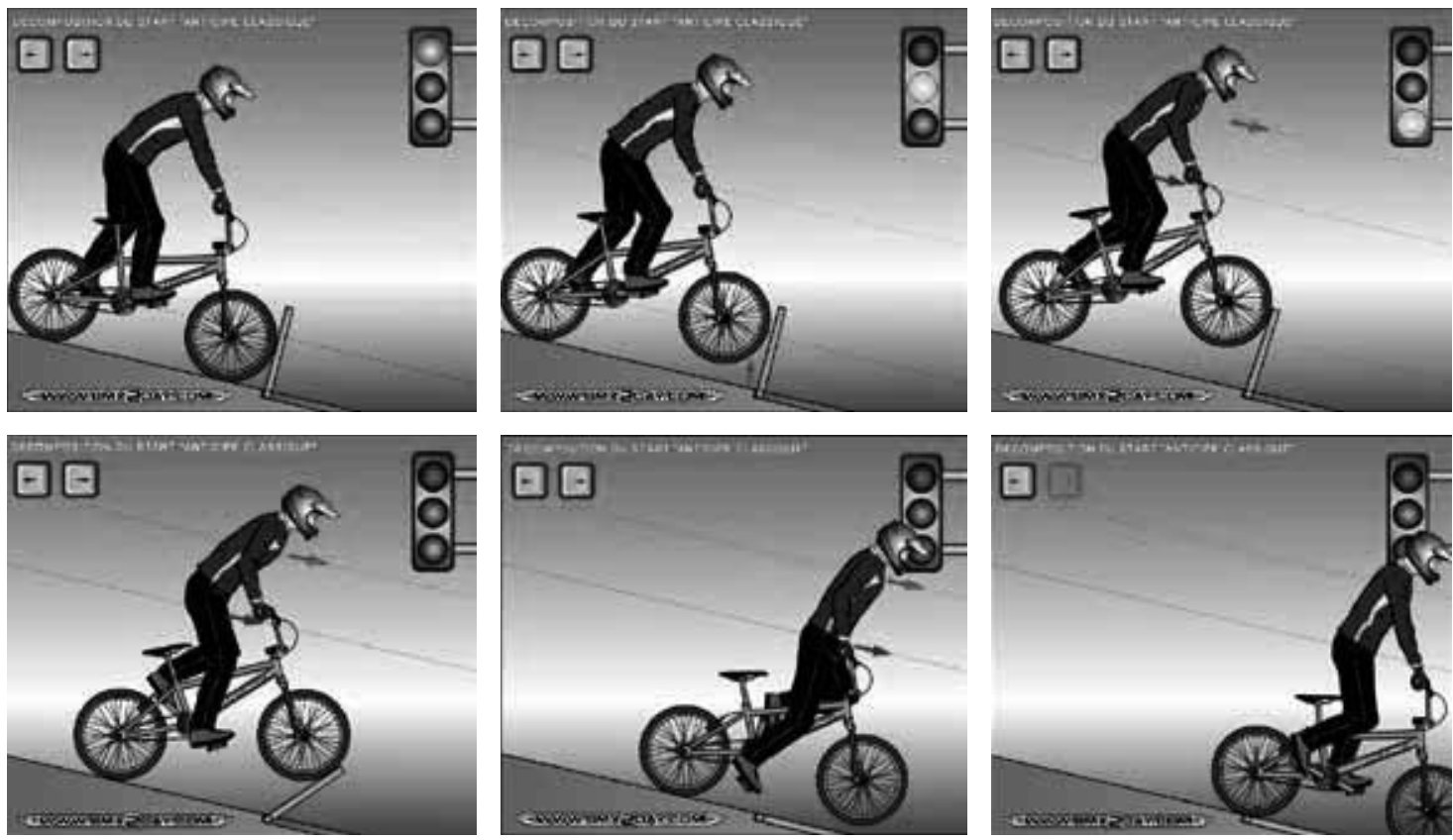

Obr. 4 Kinogram klasického startu s pohybem kola vzad: a) přípravná startovní pozice, b-c) fáze pohybu kola vzad, d-f) fáze zrychlení (Převzato od Dorémus, 2011)

\section{Fáze zrychlení}

V této fázi pokračuje pohyb kyčlí k řídítkům. Současně s ním vyvíjí jedna noha tlak do předního pedálu, druhá táhne zadní pedál nahoru (obr. 4d). Ramena, kyčle a kotníky se tak dostávají do jedné roviny (obr. 4e). Jezdec přenesl celou svou hmotnost nad přední část kola, aby minimalizoval účinek reakčních sil od pedálů a také přetáčení kola, jak vysvětluje Lefebvre (2010). Pánev svým posunem až k řídítkům také umocňuje hybnost prvního šlápnutí. Ve chvíli, kdy je přední noha dole, posuneme těžiště vzad, čímž pod sebou kolo podsuneme vpřed, a to nám umožní snadněji navázat druhým šlápnutím (obr. 4f). Přední kolo položíme těsně za rampu ve chvíli, kdy mříž dopadne na zem. Účelem této fáze je využít všechnu energii nakumulovanou ve svalech během předchozí fáze. Téměř všechna kloubní spojení jdou do extenze, s výjimkou zadní dolní končetiny.

Každá z těchto fází trvá jen několik desetin sekundy. Krátká reakční doba umožňuje jezdci provést větší pohyb zpět, a tím akumulovat víc potenciální energie pružnosti, což se projeví na síle zrychleného startovního pohybu. Člověk reaguje rychleji na zvukový podnět než na vizuální. Při startu by tedy obecně mělo být výhodnější využívat zvukového signálu než světelného.

Časoprostorovými charakteristikami tohoto startu se zabýval Gianikellis a kol. (2011). Na základě 3D kinematické analýzy tř́ špičkových jezdců BMX rozebral základní charakteristiky techniky startovní fáze. Gianikellis a kol. (2011) došel k závěru, že rychlost provedení startovní fáze závisí především na svalových dispozicích a na těchto faktorech techniky: rychlosti reakce na startovní signál, rychlosti a rozsahu pohybu a náklonu trupu vpřed. Při nedostatku jednoho a nadprůměrné úrovni druhého z těchto dvou základních předpokladů - technické vyspělosti a svalových dispozic, můžeme v praxi pozorovat jistou suplicitu faktorů.

\section{Start „slingshot“}

Jedná se o nový typ startu, který je založen na zahájení zpětného pohybu, ještě než začne padat mříž. Tento start charakterizuje Dorémus (2011): Přední pedál je v př́ípravné pozici o něco níž než obvykle, nebo alespoň rovnoběžně se zemí. Pootočením pedálů v opačném směru se jezdec posouvá o něco vzad, poté sešlápne dopředu a se současným tlakem do pedálů tlačí pánev vpřed. Výhodou tohoto předčasné- 
ho pohybu je zisk hybnosti. Když se jezdec vrací dopředu a přejíždí mříž, už má jistou rychlost, kterou získal právě tímto zpětným pohybem. Nicméně tento typ startu je v praxi riskantní, protože jezdec musí zahájit sešlápnutí vzad ještě před startovním signálem, jak ukazuje obr. 5. Pokud vystartuje př́liš brzy nebo neprovede zpětný pohyb ve stejné intenzitě jako obvykle, hrozí mu při návratu vpřed tvrdý náraz do mřiže. Naopak jestliže start zahájí o něco později, bude pak i ze startovního zařízení vyjiždět oproti ostatním se zpožděním.
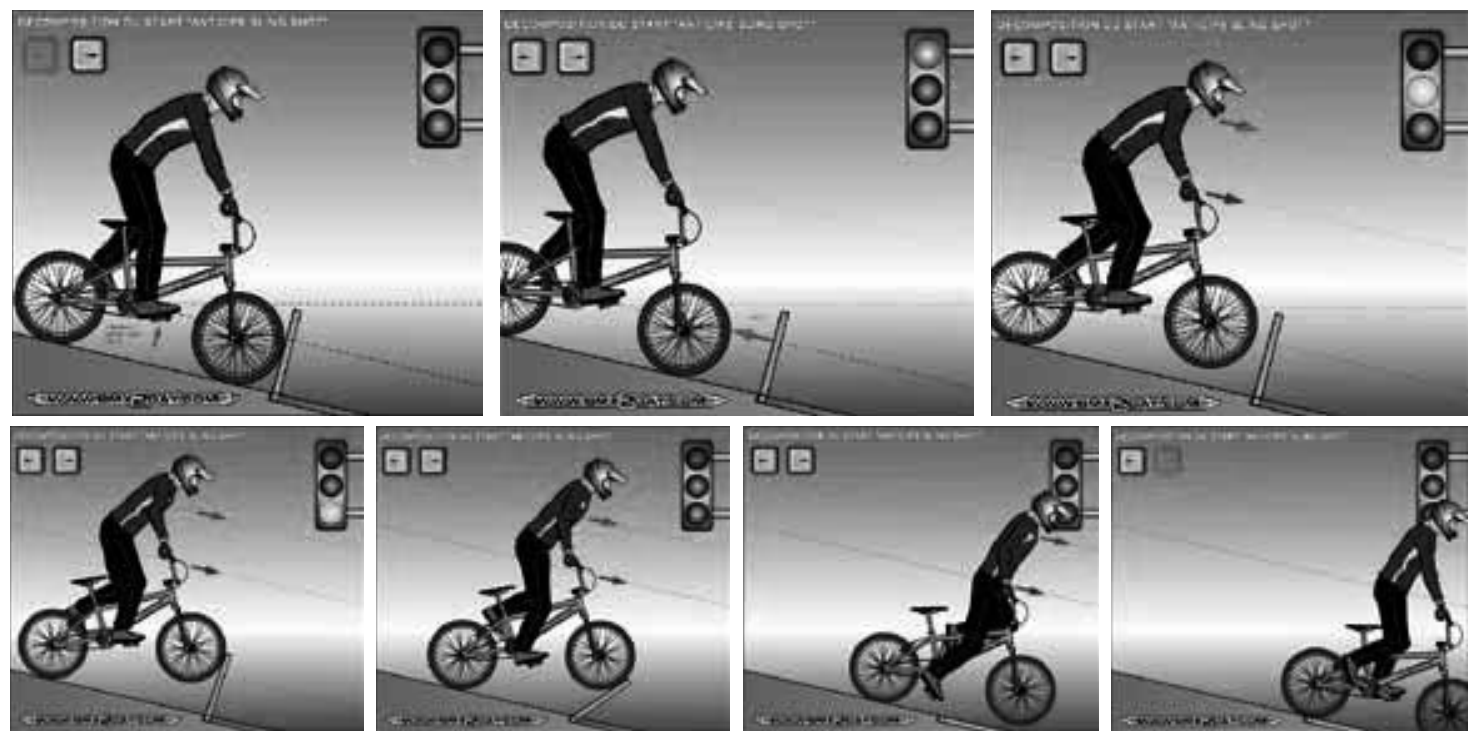

Obr. 5 Kinogram startu typu „slingshot“ (Převzato od Dorémus, 2011)

\section{CYKLUS ŠLAPÁNÍ Z HLEDISKA BIOMECHANIKY}

Základním pohybem př̀i jízdě na BMX, at už na trati či při samotném startu, je cyklus šlapání. Jak jsme uvedli, úspěšnost startu závisí mimo jiné i na velikosti výbušné síly dolních končetin, které svým tlakem či tahem způsobují otáčivý pohyb klik, a tím uvádějí kolo do pohybu. Při hlubším porozumění problematice šlapání z hlediska biomechaniky zjištujeme, že zrychlení při startu není jen otázkou vynaložení nadprůměrně velké síly, ale i otázkou jejího směru.

Otáčivý pohyb klik je uskutečňován napínáním a uvolňováním odpovídajících svalových skupin, které produkují síly určitého směru a velikosti (obr. 6).
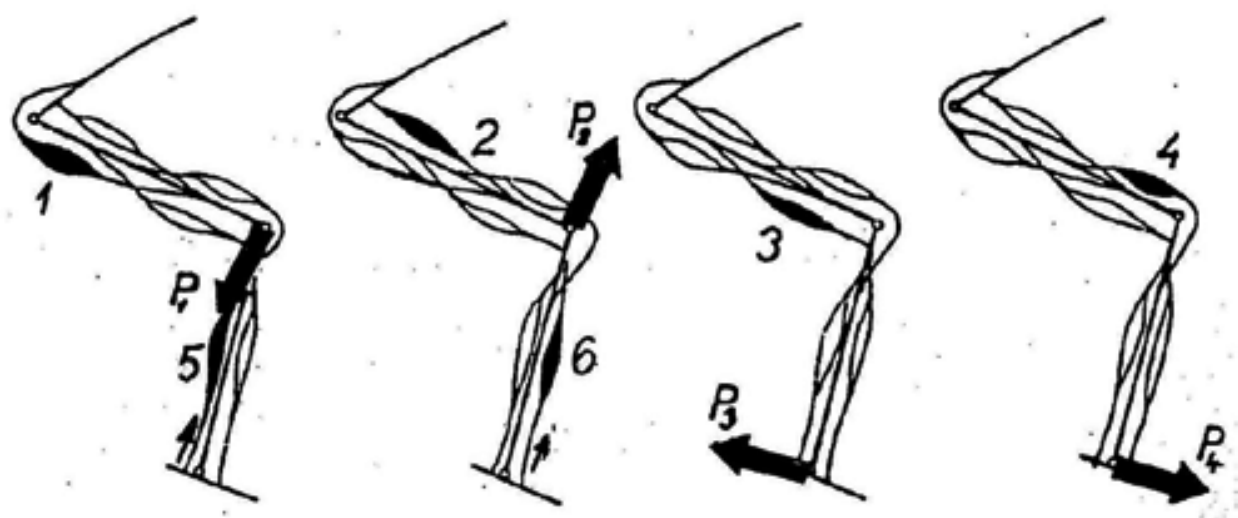

Obr. 6 Schéma působících sil a měnících se zapojovaných svalů (Převzato od Cibula, 2004) 
V průběhu celého cyklu otáčení klik o $360^{\circ}$ se tyto síly mění, každá noha je vždy v jiné fázi. Cibula (2004) připomíná, že zapojované svaly se rychle stř́idají, proto je třeba tréninkem jejich práci optimalizovat tak, aby nedošlo k překrývání jejich činnosti a vzájemnému protipůsobení a vynaložená energie byla optimálně využita. K co nejefektivnějšímu šlapání je zapotřebí, aby směr síly působící na pedál byl ve směru tečny ke kruhovému pohybu. V tom případě je otáčivý účinek síly na pedály největší. Tato ideální síla je výsledkem vertikální složky způsobené tlakem dolů či tahem nahoru, a horizontální složky způsobené tlakem a tahem vpřed či vzad, jak ukazuje obr. 7 (Konopka, 2007).

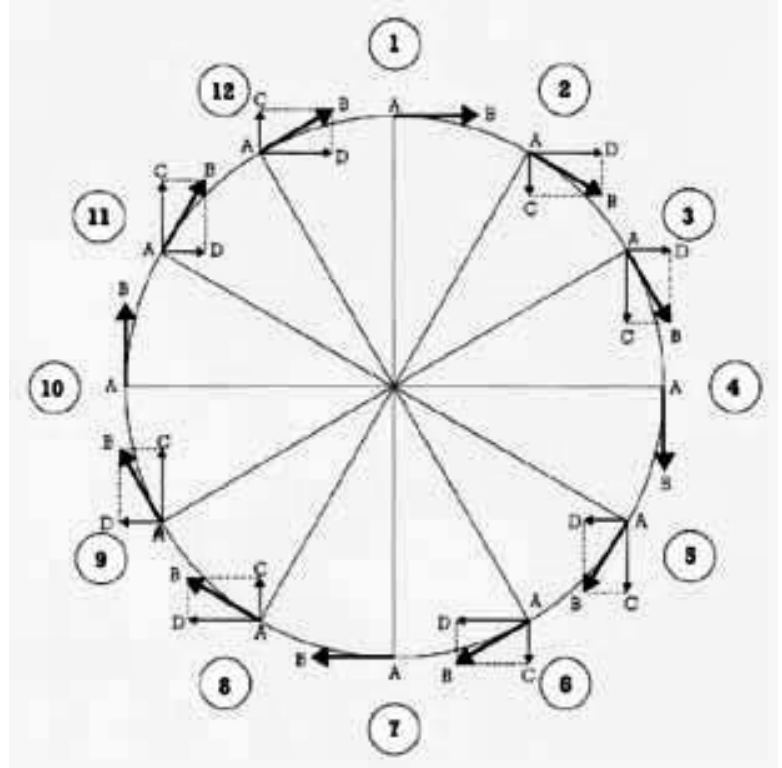

Obr. 7 Síly působící během celého otočení klikou (převzato od Konopka, 2007)

Henke a kol. (1998) rozdělil cyklus šlapání na čtyři fáze:

1. Mrtvý bod nahoře $\left(315-45^{\circ}\right)$ - fáze přechodu mezi flexí a extenzí segmentů dolní končetiny. Odpovídá oblasti svalové inaktivity díky svalové inhibici v této výseči (Belluye a Cid, 2001).

2. Hlavní pohybová fáze $\left(45-135^{\circ}\right)$ - fáze extenze dolní končetiny. Šlapánív této výseči je nejúčinnější.

3. Mrtvý bod dole (135-225 ) - fáze přechodu mezi extenzí a flexí dolní končetiny. Velikost působící svalové síly se zmenšuje a její vektor má tendenci nabývat neúčinného směru (Belluye a Cid, 2001).

4. Fáze tahu $\left(225-315^{\circ}\right)$ - fáze přechodu dolní končetiny do flexe. V této fázi se setkáváme se třemi možnými př́pady:

- Dolní končetina nevyvíjí žádnou tahovou sílu, pouze leží na pedálu a její hmotnost vytváří odpor proti otáčení klik;

- Dolní končetina působí vzhůru silou odpovídající její vlastní tíze;

- Dolní končetina působí v tahu větší silou než je její vlastní tíha, aktivně se tedy podílí na otáčení klik.

V mnohých studiích odborníci měřili pomocí tenzometrů a piezoelektrických snímačů síly vznikající při šlapání (Broker a kol., 1990, Kautz a kol., 1991, 1993, Caldwell a kol., 1998). Výsledky ukázaly, že se oproti optimálnímu teoretickému modelu kulatého šlapání mění průběh velikostí složek síly v jednotlivých kvadrantech.

Cyklem šlapání v BMX se zabýval Campillo a kol. (2007). Cílem jeho studie bylo analyzovat vliv délky klik na kinematické a dynamické proměnné při cyklu šlapání na BMX. Výsledky poukázaly na výhodu delších klik z hlediska kinematických parametrů, na získané lineární a úhlové rychlosti. Nepotvrdila se však jejich přednost $\mathrm{z}$ hlediska dynamiky, co se týče velikosti vyvinuté síly, naopak byly naměřeny větší síly u kratších klik. 
Co se týče šlapání při samotném bikrosovém startu, můžeme při jízdě ze startovního navýšení rozeznat dva typy. Nejdříve jde o šlapání založené na vyvinuté síle, kterou je třeba maximalizovat a směrově optimalizovat. Tento silový typ šlapání se postupně mění ve šlapání založené na rychlosti, které již nevyžaduje působení tak velké svalové síly, ale podstatnější je frekvence šlapání. V obou prŕpadech je třeba minimalizovat fáze mrtvých bodů. Toho je možné podle Doréma (2011) dosáhnout dvěma způsoby:

- pohybem pánve vpřed při každém půlotočení kliky až do momentu, kdy šlapání dostatečně přejde ze silového způsobu na rychlostní. Paže by měly po každém pootočení klik potlačit kolo dopředu, zatímco pánev se přesouvá vzad, aby mohla jít znovu vpřed při dalším průchodu klik mrtvým bodem.

- dorzální extenzí hlezenního kloubu, která v dolním mrtvém bodě dovolí tlačit kliku přes vertikálu, a tím podporuje přemístění druhé kliky přes horní mrtvý bod do hlavní pohybové fáze.

\section{Kineziogická analýza bikrosového startu}

Při bikrosovém startu pracuje tělo jako celek, nicméně nejdůležitější je práce dolních končetin. Při startovní pozici jezdec stojí v pedálech, silnější dolní končetinu má vpředu, kolenní i kyčelní klouby jsou ve flexi, hlezenní klouby pak ve flexi dorzální. Během pohybu vykonává každá dolní končetina jiný pohyb. Přední (záběrová) dolní končetina vykonává tlak, zadní naopak tah. Při tlaku na pedál dochází k extenzi v kyčelním a kolenním kloubu a k plantární flexi hlezenního kloubu. Extenzi v kyčelním kloubu zabezpečují svaly: $\mathrm{m}$. glutaeus maximus, $\mathrm{m}$. semitendinosus, $\mathrm{m}$. semimembranosus, $\mathrm{m}$. biceps femoris. Extenzi v kolenním kloubu zabezpečuje m. quadriceps femoris. Na plantární flexi se podílí m. triceps surae.

Zadní noha je tahová a zvedá pedál nahoru. To umožňují flexory kyčelního kloubu - m. iliopsoas, m. rectus femoris, flexory kolenního kloubu $-\mathrm{m}$. biceps femoris, $\mathrm{m}$. semitendinosus, $\mathrm{m}$. semimembranosus a dorzální flexory hlezna $-\mathrm{m}$. tibialis anterior.

Přechod mezi těmito dvěma hlavními pohyby - tlakem a tahem - by měl být optimalizován tak, aby se šlapání co nejvíce blížilo nejúčinnějšímu kulatému šlapání. Obr. 8 ukazuje účinné kulaté a nežádoucí př́močaré šlapání, kde je markantní rozdíl zejména v práci hlezenního kloubu.

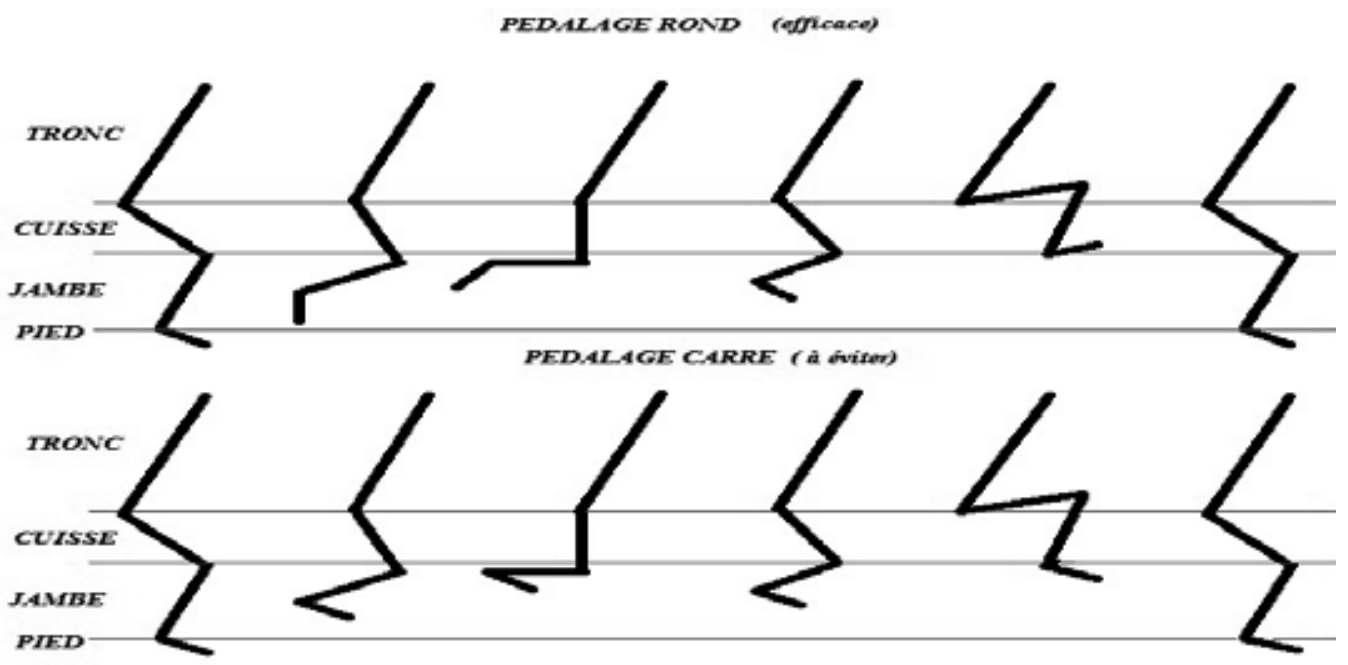

Obr. 8 Kulaté (nahoře) a přímočaré (dole) šlapání (Převzato od Lefebvre, 2010)

V horní polovině těla dochází během startovního pohybu k napřímenému držení trupu - m. erector spinae, m. quadratus lumborum. Izometrická činnost těchto svalů vytváří z trupu pevný segment umožňující optimální přenos sil mezi horními a dolními končetinami. Dále dochází k extenzi ramenních 
kloubů - m. deltoideus (hřebenová část), m. latissimus dorsi, m. triceps brachii, a k flexi v loketních kloubech $-\mathrm{m}$. biceps brachii, $\mathrm{m}$. brachialis, $\mathrm{m}$. brachioradialis.

Mnozí autoři (Ryan a kol., 1992, Marsh, Martin, 1995, Neptune a kol., 1997, Li a kol., 1998, Baum a kol., 2003) měřili pomocí povrchové elektromyografie aktivitu svalů dolních končetin podílejících se na šlapání.

Činnost svalů při samotném bikrosovém startu sledovala Horáková (2010), která se zaměřila na svaly dolních končetin, a Šimeček (2010), který měřil svaly horní poloviny těla, tedy trupu a horních končetin. Kromě toho, že potvrdili činnost výše uvedených svalů pracujících při startu, Horáková (2010) uvádí, že během startu je u dolních končetin nejvíce aktivovaným svalem $\mathrm{m}$. quadriceps femoris, zejména jeho vnitřní hlava m. vastus medialis. Šimeček (2010) určil jako nejvíce pracující sval horní poloviny těla m. latissimus dorsi.

\section{ZÁVĚRY}

V této studii jsme se věnovali bikrosovému startu jako jednomu z limitujících faktorů výsledného výkonu při závodě. Popsali jsme techniky používaných typů startu, rozebrali jsme prŕípravnou startovní pozici i následující pohyby jednotlivých segmentů. Biomechanickým přístupem jsme přiblížili techniku z hlediska optimalizace šlapání na základě korekce směru vynaložené síly. Kineziologická analýza poukázala na jednotlivé pohyby tvořící bikrosový start a na aktivitu odpovídajících svalových skupin. Touto kompilační prací jsme vytvořili teoretický základ pro další výzkumy, zejména biomechanické a kineziologické, zabývající se bikrosovým startem.

\section{Literatura}

BARTŮNĚK, K. Trenér cyklistiky - BMX. Praha: Metodické oddělení ČÚV ČSTV prostřednictvím podniku ČO ČSTV Sportpropag, 1990. 56 s.

BAUM, B. S., LI, L. Lower extremity muscle activities during cycling are influenced by load and frequency. J. Electromyogr. Kinesiol., 2003, 13, s. 181-190.

BELLUYE, N., CID, M. Approche biomécanique du cyclisme moderne, données de la littérature. Sci Sports, 2001, 16, s. 71-87.

BERTUCCI, W., HOURDE, C., MANOLOVA, A., VETTORETTI, F. Mechanical performance factors of the BMX acceleration phase in trained riders. Science \& Sports, 2007, 22, s. 179-181.

BROKER, J. P., GREGOR, R. J. A dual piezoelectric element force pedal for kinetic analysis of cycling. Int. J. Sport Biomech., 1990, 6, s. 394-403.

CALDWELL, G. E., LI, L., MCCOLE, S. D. Pedal and crank kinetics in uphill cycling. J. Appl. Biomech., 1998, 14, s. 245-259.

CAMPILLO, P., DOREMUS, T., HESPEL, J.-M. Pedaling analysis in BMX by telemetric collection of mechanic variables. Brazilian Journal of Biomotoricity. 2007, 1(2), s. 15-27.

CIBULA, K. Mechanika jízdního kola. Praha: Vydavatelství ČVUT, 2004. 2. vyd. 93 s. ISBN 80-01-03016-4. DEBRAUX, P. Etude des determinants de la performance en cyclisme. Disertační práce, 2010.[cit. 20. 8. 2011]. Dostupné na WWW: <http://ebureau.univreims.fr/slide/files/quotas/SCD/theses/ sciences/2010REIMS013.pdf>

DORÉMUS, T. Le départ en BMX. 2011. [cit. 20. 8. 2011]. Dostupné na WWW: <http://www.bmx2day. com/lebmx/coatch/lestart.php>

DOVALIL, J. a kol. Výkon a trénink ve sportu. Praha: Olympia, 2002. 331 s. ISBN 80-7033-760-5.

GIANIKELLIS, K., SKIADOPOULOS, A., BOTE, A. 3D kinematics applied to the study of individual BMX gate start technique. Portuguese Journal of Sport Sciences, 2011, 11 (2).

HORÁKOVÁ, J. Analýza bikrosového startu pomocí elektromyografie. Brno, 2010. 83 s. Diplomová práce. Masarykova univerzita.

KAUTZ, S. A., FELTNER, M. E., COYLE, E. F. The pedalling technique of elite endurance cyclists: changes with increasing workload at constant cadence. Int. J. Sport Biomech., 1991, 7, s. 29-53. 
KAUTZ,S. A., HULL, M. L. A theoretical basis for interpreting the force applied to the pedal in cycling. J. Biomech., 1993, 26, s. 155-165.

KONOPKA, P. Cyklistika. Praha: Nakladatelství jh, 2007. 200 s. ISBN 978-80-254-0258-0.

LEFEBVRE, B. Le départ. Dossier UF1 - BMX, 2010. [cit. 20. 8. 2011]. Dostupné na WWW: <http://beaunebmx.free.fr/bmxdoc/uf1_start.doc>

LI, L., CALDWELL, G. E. Muscle coordination in cycling: effect of surface incline and posture. J. Appl. Physiol., 1998, 85, s. 927-934.

MARSH, A. P., MARTIN, P. E. The relationship between cadence and lower extremity EMG in cyclists and noncyclists. Med. Sci. Sports Exerc., 1995, 27, s. 217-225.

MATEO, M., BLASCO-LAFARGA, C., ZABALA, M. Pedaling power and speed production vs. technical factors and track difficulty in BMX cycling. J Strength Cond Res, 2011, 25(X): 000-000.

NEPTUNE, R. R., KAUTZ, S. A., HULL, M. L. The effect of pedalling rate on coordination in cycling. J. Biomech., 1997, 30, s. 1051-1058.

RYAN, M. M., GREGOR, R. J. EMG profiles of lower extremity muscles during cycling at constant workload and cadence. J. Electromyogr. Kinesiol., 1992, 2, s. 69-80.

ŠIMEČEK, R. Hodnocení efektivity rozvoje silových schopností bikera s využitím elektromyografie. Brno, 2010. 87 s. Diplomová práce. Masarykova univerzita.

ZABALA, M., SANCHEZ-MUNOZ, C., MATEO, M. Effects of the administration of feedback on performance of the BMX cycling gate start. Journal of Sports Science and Medicine, 2009, 8, s. 393-400.

HENKE, T. Real-time feedback of pedal forces for the optimisation of pedalling technique in competitive cycling. Symposium of the International Society of Biomechanics in Sports. Allemagne, University of Constance, 1998. 